\title{
Detection of Mycoplasma agalactiae Antigen in Sheep and Goats by Monoclonal Antibody- Based Sandwich ELISA
}

\author{
D. ZENDULKOVÁ, ${ }^{1}$ H. J. BALL, ${ }^{2}$ A. MADANAT ${ }^{1}$, P. LÁNY ${ }^{1}$, Z. POSPÍŠIL ${ }^{1}$ \\ ${ }^{1}$ Department of Infectious Diseases and Veterinary Epidemiology, University of Veterinary \\ and Pharmaceutical Sciences Brno, Czech Republic \\ ${ }^{2}$ Veterinary Science Division, Belfast, United Kingdom \\ Received June 2, 2004 \\ Accepted October 26, 2004
}

Abstract

Zendulková D., H. J. Ball, A. Madanat, P. Lány, Z. Pospíšil: Detection of Mycoplasma agalactiae Antigen in Sheep and Goats by a Monoclonal Antibody-Based Sandwich ELISA, Acta Vet. Brno 2004, 73: 461-464.

A preliminary epidemiological survey was carried out to find out whether contagious agalactia of sheep and goats was present in herds in the Czech Republic or Jordan. A total of 99 animals were examined for the presence of Mycoplasma agalactiae antigen; there were 64 animals from the Czech Republic and 35 from Jordan. All Jordanian animals showed signs of clinical disease. Biological materials for examination included 353 swabs (133 from sheep and 220 from goats) collected from conjunctival, nasal and vaginal mucosae and the external ear canal. A monoclonal antibody-based sandwich ELISA was used to detect the antigen. The results were positive in 11 animals, ambiguous in 10 animals and negative in the rest of them (78). They confirmed our assumption that the Czech Republic is still free from contagious agalactia of sheep and goats but demonstrated that Jordanian herds of small ruminants are infected with Mycoplasma agalactiae.

Sheep, goats, contagious agalactia, antigen, Mycoplasma agalactiae, ELISA

Mycoplasma agalactiae (M. agalactiae) is an important pathogen of small ruminants that causes contagious agalactia in sheep and goats (Bergonier et al. 1997). The disease primarily affects the mammary glands, joints, eyes and, to a lesser degree, respiratory tract. It is clinically manifested as mastitis, arthritis, conjunctivitis and pneumonia (Nicholas 1996). However, similar clinical and pathological changes in these animals can also be caused by mycoplasma species (Nicholas 1996; Sarris 1996; Bölske 1994) included into the "Mycoplasma mycoides cluster" (Mycoplasma mycoides subsp. mycoides LC, Mycoplasma capricolum subsp. capricolum and Mycoplasma mycoides subsp. capri). A very similar disease found only in goats is caused by Mycoplasma putrefaciens (B ergonier et al. 1997).

Contagious agalactia currently occurs in most of the countries with intensive rearing of sheep and goats. This involves the Mediterranean region and Balkan Peninsula in Europe, western parts of Asia and northern, central and eastern Africa (Al-Zeftawi 1979; Damdinsuren 1989; Erdag 1989; Belaid et al. 1990; Da Massa et al. 1992; Ismail 1993; Sarris 1996; Egwu et al. 1999; Kusiluka et al. 2000; Madanat et al. 2001).

In this preliminary epidemiological survey we examined animals from randomly selected Czech and Jordanian herds for the presence of $M$. agalactiae antigen. In the former Czechoslovakia, the mycoplasma causing contagious agalactia was last detected in sheep imported into the country at the beginning of the 1950s (Koppel 1982). The disease was then managed by culling all the infected animals and, since then, the Czech Republic has been regarded as free from contagious agalactia. Our objective was to confirm this assumption. On the other hand, Jordan is located in the geographical area in which contagious agalactia shows a high prevalence, but no information on mycoplasma infections in Jordanian sheep and goats has so far been available.

Address for correspondence:

Doc. MVDr. D. Zendulková, CSc.

Department of Infectious Diseases and Veterinary Epidemiology

University of Veterinary and Pharmaceutical Sciences

Palackého 1-3, 61242 Brno

Czech Republic 
Animals examined

Materials and Methods

The animals from the Czech Republic included a total of 64 sheep and goats from various herds selected on a random basis. There were 32 sheep (Suffolk and Merino Landschaf ewes) and 32 goats (12 adult goats and 10 male and 10 female young animals of the Czechoslovak White Polled breed)

All animals came from farms free of any apparent clinical disease symptoms, except for one sheep herd that had had a history of respiratory disease 12 months prior to examination by our team.

The 35 Jordanian animals came from the Al- Karak district. They comprised 15 Awassi sheep and 20 goats of the local Baladi breed. At the time of sample collection these animals showed a wide range of clinical signs. Nonspecific symptoms such as anorexia, depression or somnolence were found in six sheep and four goats. Varying stages of mastitis were diagnosed in 12 animals ( 3 sheep and 9 goats), seven animals (4 sheep and 3 goats) had arthritis and six animals ( 2 sheep and 4 goats) suffered from conjunctivitis and respiratory disease.

Sampling

The samples included swabs from conjunctival, nasal and vaginal mucosae and also from the external ear canal. A total of 353 swabs were collected: 133 were from sheep (Czech Republic 106; Jordan 27) and 220 from goats (Czech Republic 140; Jordan 80). The swabs were immediately placed in test tubes containing transport medium for mycoplasma culture. The transport medium for Jordanian samples was supplemented with $1 \times g$ cefaperazone $/ \mathrm{ml}(90 \%$ cefaperazone sodium, Sigma, Aldrich Chemie GmbH, catalogue no. C4292 - 1G). The Czech samples were frozen at $-80^{\circ} \mathrm{C}$ until use. Because no deep freezer was available in Jordan, the samples were stored at $-20{ }^{\circ} \mathrm{C}$ until transported to the Czech Republic. They were collected by a Jordanian student for his PhD studies carried out at the Department of Infectious Diseases and Veterinary Epidemiology, Veterinary and Pharmaceutical University in Brno, Czech Republic.

All samples of biological material collected in Jordan were transferred under the rules set by the State Veterinary Administration of the Czech Republic.

Detection of $M$. agalactiae antigen

The $M$. agalactiae antigen was detected using a monoclonal antibody-based sandwich ELISA (Mabs - based sandwich ELISA) (Ball et al. 1993; Ball et Finlay 1998). This test was developed and kindly provided by Dr. Hywell J. Ball, Veterinary Sciences Division, Department of Agriculture for Northern Ireland in Belfast, Northern Ireland, United Kingdom.

\section{Results}

Using the ELISA method, the presence of M. agalactiae antigen was detected in 11 out of 99 animals examined (11\%). In ten animals $(10 \%)$ the results were regarded as ambiguous and in $78(79 \%)$ animals they were negative. All the positive and ambiguous results were obtained with swabs collected from small ruminants in Jordan. Out of 35 animals examined (15 sheep and 20 goats), M. agalactiae antigen was detected in two sheep and nine goats and ambiguous results were obtained in two sheep and eight goats. None of the 64 Czech animals (32 sheep and 32 goats) tested positive or showed ambiguous results.

The presence of $M$. agalactiae antigen in swabs collected from different body sites of Jordanian sheep and goats is shown in Table 1.

Table 1

Detection of Mycoplasma agalactiae in Jordanian sheep and goats

\begin{tabular}{|c|c|c|c|c|}
\hline \multirow{2}{*}{$\begin{array}{c}\text { No. of } \\
\text { animals examined }\end{array}$} & Body site & \multicolumn{3}{|c|}{ Results by ELISA Ag } \\
\hline & & + & $+/-$ & - \\
\hline Sheep & Conjunctiva & 1 & 0 & 11 \\
\hline $\mathrm{n}=15$ & Nasal mucosa & 1 & 1 & 13 \\
\hline & Vaginal mucosa & 0 & 1 & 13 \\
\hline & External ear canal & 0 & 3 & 47 \\
\hline$\Sigma$ & 52 & 2 & $+/-$ & 16 \\
\hline Goats & & + & 3 & 16 \\
\hline $\mathrm{n}=20$ & Conjunctiva & 2 & 1 & 17 \\
\hline & Nasal mucosa & 1 & 0 & 9 \\
\hline & Vaginal mucosa & 7 & 4 & 59 \\
\hline
\end{tabular}




\section{Discussion}

Although the last reports on sheep and goats infected with contagious agalactia date back to the 1950s in the former Czechoslovakia (Koppel 1982), the threat of re-introduction of this highly contagious, devastating disease should always be kept in mind in a country that, like the Czech Republic, is open to animal import and serves as a transit area. This was the reason why we designed a preliminary study to ascertain whether our farms were still free of this disease. This survey is related to our previous study in which small ruminants were examined for specific antibodies against M. agalactiae and which gave negative results (Madanat et al. 2002).

In Arabian countries, however, the situation is completely different. Contagious agalactia is a permanent health and economic problem (Belaid et al. 1990). In our previous study we demonstrated the presence of specific antibodies against $M$. agalactiae in Jordanian sheep and goats (Madanat et al. 2002). In this study the demonstration of contagious agalactia in small ruminants in Jordan was completed by the detection of M. agalactiae antigen.

The detection of Mycoplasma spp. is so far most frequently carried out in culture. However, this method is time consuming and laborious. For the identification of Mycoplasma spp., several antigen-capture and sandwich modifications of ELISA are available but they have been used only in research laboratories because of their low sensitivity in comparison with standard culture techniques. In this study we employed for the detection of $M$. agalactiae antigen a specific enzyme-linked immunosorbent assay, the Mabs-based sandwich ELISA (B all et al. 1993; B all et Finlay 1998). This technique has particular advantages, since Mycoplasma spp., despite well-documented problems with species crossreactivity and interference by nonspecific media components, are largely speciated by serological methods. This Mabs-based sandwich ELISA involves preenrichment, a short-term incubation of the sample directly on an ELISA plate, and the use of monoclonal antibodies; the former renders the method more sensitive and the latter facilitates its better reproducibility and increases its specificity. The use of this ELISA method improves laboratory diagnosis of infectious agalactia also in terms of reliability, accuracy and time, which is very important because some infected sheep and goats have shown atypical forms of the disease (Nicolet 1994b); in addition, asymptomatic disease carriers have been reported (B erg onier 1996ab; Lillini et al. 1996; S an chis et al. 2000) which are difficult to detect by less sensitive laboratory methods.

The results of our study confirmed that Czech herds are currently free from contagious agalactia of sheep and goats and, at the same time, provided the first information on the presence of $M$. agalactiae, a pathogen causing contagious agalactia of sheep and goats, in Jordanian herds.

\section{Průkaz antigenu Mycoplasma agalactiae u ovcí a koz pomocí ELISA metody sendvičového typu založené na bázi monoklonálních protilátek}

Byla provedena předběžná epizootologická studie s cílem zjistit, zda se v chovech České republiky a Jordánska vyskytuje nakažlivá agalakcie ovcí a koz. Celkem bylo na přítomnost antigenu Mycoplasma agalactiae vyšetřeno 99 zviŕat, 64 zvířat pocházelo z České republiky a 35 z okresu Al-Karak v Jordánsku. Všechna zvířata jordánského původu vykazovala klinické příznaky probíhajícícho onemocnění. Celkem bylo vyšetřeno 353 vzorků výtěrů (od ovcí 133 a 220 od koz), odebraných ze sliznice spojivkové, nosní, vaginální či ze zevního zvukovodu. K detekci antigenu byla použita ELISA metoda sendvičového typu založená na bázi monoklonálních protilátek. Pomocí této metody bylo zjištěno 11 zvířat pozitivních, 10 dubiózních a 78 negativních. Tyto výsledky jsou potvrzením našeho původního předpokladu, že Česká republika je stále dosud nakažlivé agalakcie ovcí a koz prostá, na druhé straně však prokázaly, že stáda ovcí a koz v Jordánsku jsou infikována Mycoplasma agalactiae. 


\section{Acknowledgements}

This study was supported by the Research Plan MSM 161700001 of the Ministry of Education, Youth and Sports of the Czech Republic and by the international project COST 826.10 from the European Union.

\section{References}

AL - ZEFTAWI, NMN 1979: The role of Mycoplasmatales in diseases of sheep and goats in Egypt. PhD. Thesis. University of Cairo, Cairo, $180 \mathrm{pp}$.

BALL, HJ, KERR, S, MACKIE, DP 1993: Monoclonal antibody-based ELISAs. In: Kroll, RG, Gilmour, A and Sussman, M: New Techniques in Food and Beverage Microbiology. Blackwell Scientific Press, 180 pp.

BALL, HJ, FINLAY, D 1998: Diagnostic Application of Monoclonal Antibody (MAb)- Based Sandwich ELISAs. In: Miles, R. and Nicholas, R.: Mycoplasma Protocols. Humana Press, 330 pp.

BELAID, B, LE GOFF, C, LEFEVRE, P 1990: Enquete épidémiologique et sérodiagnostic de l'agalactie contagieuse des petits ruminants de 1'Est algérien. Rev Elev MedVet Pays Trop 43: 37--41

BERGONIER, D 1996a: Étude de la variabilité intra-spécifique de Mycoplasma agalactiae: bases pour l'amélioration du diagnostic de l'agalactie contagieuse. PhD. Thesis. Université Claude Bernard, Lyon, $205 \mathrm{p}$.

BERGONIER, D, DE SIMONE, F, RUSSO, P, SOLSONA, M, POUMARAT, F 1996b: Variable expression and geographic distribution of Mycoplasma agalactiae surface epitopes demonstrated with monoclonal antibodies. FEMS Microbiol Lett 143: 159-165

BERGONIER, D, BERTHELOT, X, POUMARAT, F 1997: Contagious agalactia of small ruminants: current knowledge concerning epidemiology, diagnosis and control. Rev Sci Tech OIE 16: 848-873

BÖLSKE, G, WILHEMSSON, E, TWINAMASIKO, E, JOHANSSON, KE 1994: Detection of Mycoplasma capricolum subsp. capripneumoniae in goats and sheep in Uganda. IOM. Lett. 3: 19-20

DA MASSA, AJ, WAKENELL, PS, and BROOKS, DL 1992: Mycoplasmas of goats and sheep. J Vet Diagn Invest 4: 101-113

DAMDINSUREN, Ch 1989: Mycoplasmosis in farm animals in Mongolia: immunization of sheep and goats against contagious agalactia. Arch Exper Vet Med 43: 769-772

EGWU, GO et al. 1999: Caprine mycoplasmal mastitis in Nigeria. Veterinarski Arhiv. 69: 241-250

ERDAG, O 1989: Investigations on the preparation and application of vaccine against contagious Mycoplasma agalactiae or sheep and goats in Turkey. Proc Int Symp Mycoplasma Theiler 20-22

ISMAIL, SF 1993: Infectious caprine keratokonjunctivitis. Assiut Vet Med J 28: 264-271

KOPPEL, Z 1982: Infekčná agalakcia ovcí a kôz. In: Hejlíček, K, Vrtiak, JO et al.: Speciální epizootologie 1. Praha, $318 \mathrm{p}$.

KUSILUKA, LJ et al. 2000: Mycoplasmas isolated from the respiratory tract of cattle and goats in Tanzania. Acta Vet Scand 41: 299-309

LILLINI, E et al. 1996: Presence and persistence of healthy carriers in flocks affected by contagious agalactia. In: Frey, J and Sarris, K: Mycoplasmas of Ruminants: pathogenicity, diagnostics, epidemiology and molecular genetics. EUR 16934, COST, European Commision, European Communities Official Publications Office, Vol. 1: $133-135$

MADANAT, A, ZENDULKOVÁ, D, POSPÍŠIL, Z 2001: Contagious agalactia of sheep and goats. A review. Acta Vet Brno 70: 403-412

MADANAT, A, ZENDULKOVÁ, D, LÁNY, P, POSPÍŠIL, Z, ČIHAL, P 2002: Prevalence of Mycoplasma agalactiae antibodies in Czech and Jordanian herds of small ruminants. Acta Vet Brno 71: 37-44

NICOLET, J 1994: Mycoplasma infections in cattle, sheep and goats: methods for diagnosis and prophylaxis. In: Comprehensive reports on technical items presented to the International Committee or to Regional Commissions OIE, Paris, pp. 43-54

NICHOLAS, R 1996: Contagious agalactia: an update. In: Frey, J and Sarris, K: COST 826 Agriculture and Biotechnology, „Mycoplasmas of Ruminants: Pathogenicity, Diagnostics, Epidemiology and Molecular Genetics,“EUR 16934 Luxembourg, 172 pp.

SANCHIS, R, ABADIE, G, LAMBERT, M, CABASSE, E, DUFOUR, P, GUIBERT, JM, PÉPIN, M 2000 : Inoculation of lactating ewes by the intramammary route with Mycoplasma agalactiae: comparative pathogenicity of six field strains. Vet Res 31: 329-337

SARRIS, K 1996: Contagious agalactia. In: Frey, J and Sarris, K: Mycoplasmas of ruminants: pathogenicity, diagnostics, epidemiology and molecular genetics., COST 826, EUR 16934, European Commission, European Communities Official Publications Office, Luxembourg, pp. 12-15 